\title{
Analisis Efisiensi Dan Efektifitas Pajak Bumi dan Bangunan Perdesaan Dan Perkotaan (PBB-P2) dan Pengaruhnya terhadap Pendapatan Asli Daerah di Kabupaten Batang Hari
}

\author{
Neng Setiawati*, Satya Wahyudi, Novi Aulia \\ STIE Graha Karya Muara Bulian \\ *Corresponding email: setiawati888888@gmail.com
}

\begin{abstract}
This study aims to analyze the level of efficiency, effectiveness and influence of the Rural and Urban Land and Building Tax (PBB-P2) on Regional Original Income (PAD) in Batang Hari Regency. The data used in this study are primary data obtained from the Regional Finance Agency of Batang Hari Regency and secondary data by conducting library research obtained from the literature and other information related to the problem under study. The analytical tools used are descriptive analysis, growth analysis, contribution/share, efficiency and effectiveness analysis, and simple regression analysis using IBM (Statistical Package for Social Science) SPSS version 26. The results showed that the average level of efficiency of Rural and Urban Land and Building Tax collection (PBB-P2) of 82.98 percent was categorized as quite efficient. The average level of effectiveness of $P B B-P 2$ is 56.87 percent, including the less effective category. The results of the regression calculations show that the PBB-P2 variable has no effect on PAD receipts in Batang Hari Regency.
\end{abstract}

Keywords: Efficiency; Effectiveness; Urban and Rural Land and Building Tax; Regional Original Income (PAD)

\section{PENDAHULUAN}

Al hasni dalam Halim (2014) mengatakan Undang-Undang nomor 32 Tahun 2004 sebagai pengganti Undang-Undang Nomor 22 Tahun 1999 tentang Pemerintah Daerah dengan esensi kebijakan otonomi daerah, telah menempatkan Provinsi, Kabupaten, dan Kota sebagai titik berat otonomi. Dalam kaitannya dengan desentralisasi dalam hal pengelolaan keuangan daerah, sesuai yang diamanatkan Undangundang Nomor 17 Tahun 2003 tentang Keuangan Negara, maka daerah dihadapkan pada permasalahaan bagaimana daerah mampu mengelola sumber-sumber pendapatannya. Permasalahan pengelolaan sumbersumber pendapatan yang dialami daerah adalah bagaimana daerah mampu menggali, mendapatkan, dan memanfaatkan sumber daya ekonomi yang ada untuk kepentingan kesejahteraan masyarakat di daerah.

Berdasarkan Undang-Undang Nomor 28 Tahun 2009 tentang Pajak Daerah dan Retribusi Daerah bahwa pengaturan kewenangan perpajakan dan retribusi yang ada saat ini kurang mendukung pelaksanaan otonomi Daerah. Pemberian kewenangan yang semakin besar kepada Daerah dalam penyelenggaraan pemerintahan dan pelayanan kepada masyarakat seharusnya diikuti dengan pemberian kewenangan yang besar pula dalam perpajakan dan retribusi. Basis pajak kabupaten dan kota yang sangat terbatas dan tidak adanya kewenangan provinsi dalam penetapan tarif pajaknya mengakibatkan daerah selalu mengalami kesulitan untuk memenuhi kebutuhan pengeluarannya. Ketergantungan Daerah yang sangat besar terhadap dana perimbangan dari pusat dalam banyak hal kurang mencerminkan akuntabilitas Daerah. Pemerintah Daerah tidak terdorong untuk mengalokasikan anggaran secara efisien dan masyarakat setempat tidak ingin mengontrol anggaran daerah karena merasa tidak dibebani dengan Pajak dan Retribusi.

Menurut Halim, (2014), Pemerintah tentu dapat dipahami sebagai sebuah organisasi. Pemerintah dalam konteks negara pastilah bertujuan nirlaba. Dengan demikian, pemerintah atau negara tentulah termasuk dalam jenis organisasi publik. Organisasi negara dijalankan oleh pemerintah. Dalam hal ini, pemerintah sebagai pelaksana (executive) dari pemerintahan atau negara. Tujuan Pemerintah tentu melaksanakan tujuan negara. Oleh sebab itu, dapat dipahami bahwa tujuan pemerintah merupakan tujuan negara.

Mardiasmo (2001) berpendapat bahwa tujuan utama penyelenggaaan otonomi daerah adalah meningkatkan pelayanan piblik (publik service) dan memajukan perekonomian daerah. Pada dasarnya terkandung tiga misi utama pelaksanaan otonomi daerah dan desentralisassi fiskal, yaitu:

1. Meningkatkan kualitas dan kuantitas pelayanan publik dan kesejahteraan masyarakat.

2. Menciptakan efisiensi dan efektifitas pengelolaan sumber daya daerah.

3. Memberdayakan dan menciptakan ruang bagi masyarakat (publik) untuk berpartisipasi dalam proses pembangunan.

Mahmudi (2010) berpendapat apabila realisasi melampaui anggaran (target) maka kinerjanya dapat dinilai baik. Penilaian kinerja pendapatan pada dasarnya tidak cukup hanya melihat apakah realisasi pendapatan daerah telah melampaui target anggaran, namun perlu dilihat lebih lanjut komponen pendapatan apa yang paling berpengaruh. Hal ini untuk mengetahui lebih lanjut apakah pelampauan target pendapatan itu 
disebabkan Karena good planning dan kerja keras pemerintah daerah ataukah hanya semata-mata good luck saja.

Penelitian ini merupakan pengembangan dari penelitian dari Tuasikal, (2008) yang berjudul Analisis Pengaruh Pajak daerah dan Retribusi daerah Terhadap Pendapatan Asli Daerah (Studi Kasus di DPPKAD Wilayah Keresidenan Surakarta), perbedaan penelitian ini dengan penelitian sebelumnya adalah menambahkan variabel Pajak Bumi dan Bangunan sebagai salah satu jenis pajak daerah yang potensial. Sejalan dengan Utomo, (2012) yang melakukan studi empiris di wilayah Keresidenan Surakarta yaitu kabupaten Surakarta, Kabupaten Sukoharjo, Kabupaten Boyolali, Kabupaten karanganyar, Kabupaten Klaten, Kabupaten Sragen dan Kabupaten Wonogiri berpendapat bahwa secara parsial pajak daerah dan retribusi daerah berpengaruh signifikan terhadap PAD pada pemerintah kota dan pemerintah kabupaten di wilayah keresidenan Surakarta. Gitaningtyas, (2014) mengatakan dukungan keuangan Pemerintah Daerah dapat diperoleh dari Pendapatan asli Daerah (PAD),yang terdiri dari Pajak Daerah, Retribusi Daerah, Harta Kekayaan Daerah yang dipisahkan, dan Lain-lain pendapatan yang sah. PAD juga merupakan salah satu indikator atau kriteria untuk mengukur ketergantungan suatu daerah terhadap pemerintah pusat. Penerimaan PAD juga akan memberikan kontribusi yang sangat besar terhadap realisasi Anggaran Pendapatan dan Belanja Daerah.

Mukhlis, (2010) berpendapat Pendapatan Asli Daerah (PAD) memiliki peran penting dalam rangka pembiayaan pembangunan di daerah berdasarkan pada potensi yang dimiliki masing-masing daerah, peningkatan dalam penerimaan PAD ini akan dapat meningkatkan kemampuan keuangan daerah. Seiring dengan perkembangan perekonomian daerah yang semakin terintegrasi dengan perekonomian nasional dan internasional, maka kemampuan daerah dalam mengoptimalkan pemanfaatan sumber-sumber penerimaan PAD menjadi sangat penting. Sumbersumber penerimaan PAD tersebut dapat diuraikan lagi dalam bentuk penerimaan dari pajak daerah dan retribusi daerah. Pendapatan Asli Daerah (PAD) dapat dipandang sebagai salah satu indikator atau kriteria untuk mengukur tingkat ketergantungan suatu daerah kepada pemerintah pusat. Kemampuan keuangan suatu daerah dapat dilihat dari besar kecilnya PAD yang diperoleh daerah yang bersangkutan. Pada prinsipnya, semakin besar sumbangan PAD pada APBD, menunjukkan semakin kecilnya tingkat ketergantungan daerah kepada pemerintah pusat.

Hafidh, (2013) mengatakan otonomi daerah yang saat ini sudah berjalan di tiap kabupaten dan kota di Indonesia tetap menimbulkan persoalan baru, karena ternyata potensi pemerintah daerah yang satu dengan daerah yang lainnya sangat beragam, PAD yang tinggi mencerminkan keuangan daerah yang maju.

Besarnya peran masyarakat dalam pembangunan menurut Azril, (2000) dalam Badrudin, (2011) tersebut tidak terlepas dari tiga fungsi pemerintah, yaitu memelihara keamanan dan pertahanan dalam negeri, menyelenggarakan peradilan, dan menyediakan barangbarang yang tidak mampu disediakan oleh pihak swasta, seperti jalan, dam, dan sarana publik lainnya. Salah satu perangkat yang selama ini banyak digunakan oleh pemerintah untuk mewujudkan peran tersebut adalah perangkat kebijakan fiskal dalam bidang pendidikan, kesehatan, irigasi, transportasi dan sebagainya Sasana, (2009) dalam Badrudin, (2011).

\section{METODE}

\section{Jenis Penelitian}

Jenis penelitian yang akan dilakukan merupakan penelitian akademik. Penelitian akademik adalah penelitian yang dilakukan oleh dosen sebagai bentuk pengabdian akademik.

\section{Jenis dan Sumber data \\ Data Primer}

Data ini diperoleh dari Badan Keuangan Daerah Kabupaten Batang Hari. Data yang dikumpulkan adalah data yang berhubungan dengan Penerimaan Pajak Bumi dan Bangunan Perdesaan dan Perkotaan (PBB-P2) serta data Realisasi Pendapatan Asli Daerah (PAD) selama 5 (lima) tahun mulai dari tahun 2016 sampai tahun 2020.

\section{Data Sekunder}

Data yang diolah dengan mengadakan penelitian kepustakaan dengan mengumpulkan data yang diperoleh dari literatur-literatur dan informasi-informasi lainnya yang berkaitan dengan masalah yang diteliti.

\section{Metode Pengumpulan Data Kepustakaan (Library Research)}

Teknik pengumpulan data dengan cara membaca buku-buku, literatur-literatur, teori dan informasi serta sumber-sumber lain yang behubungan dengan masalah yang di teliti.

\section{Teknik Analisis Data dan Alat Analisis Teknik Analisis Data}

Teknik yang digunakan untuk menganalisa data penelitian adalah metode analisis deskriptif kuantitatif yaitu mengungkapkan kondisi temuan pada objek penelitian baik dalam bentuk data kuantitatif maupun kualitatif untuk menarik kesimpulan penelitian.

\section{Alat Analisis}

Metode analisis data yang digunakan untuk menghitung efisiensi pajak daerah adalah sebagai berikut: 
Neng Setiawati, Satya Wahyudi dan Novi Aulia, Analisis Efisiensi Dan Efektifitas Pajak Bumi dan Bangunan Perdesaan Dan Perkotaan (PBB-P2) dan Pengaruhnya terhadap Pendapatan Asli Daerah di Kabupaten Batang Hari

Efisiensi Pajak Daerah $=\frac{\text { Biaya Pemungutan PBB }-\mathrm{P} 2}{\text { Realisasi Penerimaan PBB-P2 }} \times 100 \%$

Tabel 1. Klasifikasi Kriteria Nilai Efisiensi Pajak Daerah

\begin{tabular}{cc}
\hline Persentase & Kriteria \\
\hline$>100 \%$ & Tidak Efisien \\
$90-100 \%$ & Kurang Efisien \\
$80-90 \%$ & Cukup Efisien \\
$60-80 \%$ & Efisien \\
$<60 \%$ & Sangat Efisien \\
\hline
\end{tabular}

Sumber: Kepmendagri No.690.900.327, 1996

Efisiensi Pajak Daerah $=\frac{\text { Realisasi Penerimaan PBB }-\mathrm{P} 2}{\text { Target Penerimaan PBB }-\mathrm{P} 2} \times 100 \%$

Tabel 2. Klasifikasi Kriteria Nilai Efektifitas Pajak Daerah

\begin{tabular}{cc}
\hline Persentase & Kriteria \\
\hline$>100 \%$ & Sangat Efektif \\
$90-100 \%$ & Efektif \\
$80-90 \%$ & Cukup Efektif \\
$60-80 \%$ & Kurang Efektif \\
$<60 \%$ & Tidak Efektif \\
\hline
\end{tabular}

Sumber: Kepmendagri No. 690.900.327, 1996

Kontribusi PBB $-\mathrm{P} 2=\frac{\text { Realisasi Penerimaan PBB }-\mathrm{P} 2}{\text { Realisasi Penerimaan PAD }} x 100 \%$

Tabel 3. Kriteria Kontribusi Pajak Daerah

\begin{tabular}{cc}
\hline Persentase & Kriteria \\
\hline $0,00 \%-10 \%$ & Sangat Kurang \\
$10,10 \%-20 \%$ & Kurang \\
$20,10 \%-30 \%$ & Sedang \\
$30,10 \%-40 \%$ & Cukup Baik \\
$40,10 \%-50 \%$ & Baik \\
Diatas 50\% & Sangat Baik \\
\hline
\end{tabular}

Sumber: Tim Litbang Depdagri Fisipol UGM, 1991

\section{Analisis Regresi}

Analisis regresi yang digunakan adalah adalah analisis regresi linier sederhana dengan menggunakan SPSS 26. Menurut Ramadhayanti (2019:91), uji regresi bertujuan untuk mengetahui besarnya pengaruh variabel bebas (independent) terhadap variabel terikat (dependent). Dimana suatu persamaan regresi atau persamaan penduga dibentuk untuk menerangkan pola hubungan variabel-variabel. Variabel yang diduga dinamakan variabel terikat (dependent variable). Variabel yang menerangkan variabel terikat dinamakan variabel bebas (independt variable.) Menurut Santoso (2020:384) Analisis regresi digunakan terutama untuk tujuan peramalan dimana dalam model tersebut ada sebuah variabel dependen (tergantung) dan variabel bebas (independen)

Analisis ini untuk mengetahui arah hubungan antara variabel independen dengan variabel dependen apakah positif atau negatif dan untuk memprediksi nilai dari variabel dependen apabila nilai variabel independen mengalami kenaikan atau penurunan. Data yang digunakan biasanya berskala interval atau rasio.
Menurut Sugiyono (2001: 203) analisis antara korelasi dan regresi keduanya mempunyai hubungan yang sangat erat. Setiap regresi pasti ada korelasinya, tetapi korelasi belum tentu dilanjutkan dengan regresi. Korelasi yang tidak dilanjutkan dengan regresi adalah korelasi antara dua variabel yang tidak mempunyai hubungan kausal / sebab akibat, atau hubungan fungsional.

Rumus regresi linear sederhana sebagai berikut:

$\mathrm{Y}^{\prime}=\mathrm{a}+\mathrm{bx}$

Keterangan:

$Y^{\prime}=$ Variabel dependen (nilai yang diprediksikan) (PAD)

$\mathrm{X}=$ Variabel independen (PBB-P2)

$\mathrm{a}=$ Konstanta (nilai $\mathrm{Y}$ apabila $\mathrm{X}=0$ )

$\mathrm{b}=$ Koefisien regresi (nilai peningkatan ataupun penurunan)

\section{Metode t-test (uji-t)}

Uji $\mathrm{t}$ ini digunakan untuk menguji koefesien regresi secara individu yaitu antara variabel independen dengan variabel dependen.

1. Menentukan Hipotesis

$\mathrm{H}_{0}: \mathrm{b}_{1}=0$, (tidak ada pengaruh yang signifikan antara variabel independen (X) terhadap variabel dependen (Y).

$\mathrm{H}_{1}$ : $\mathrm{b}_{1} \# \mathbf{0}$, (ada pengaruh yang signifikan antara variabel independen $(\mathrm{X})$ terhadap variabel dependen (Y).

2. Menetukan tingkat signifikan

Diuji dengan tingkat signifikan sebesar 0,05

3. Kriteria pengujian

$\mathrm{H}_{0}$ diterima apabila $\mathrm{t}_{\text {tabel }}<\mathrm{t}_{\text {hitung }}$ atau $\mathrm{t}_{\text {hitung }}>\mathrm{t}_{\text {tabel }}$

$\mathrm{H}_{0}$ ditolak apabila $\mathrm{t}_{\text {hitung }}<\mathrm{t}_{\text {tabel }}$ atau $\mathrm{t}_{\text {tebel }}>\mathrm{t}_{\text {hitung }}$

\section{Metode Analisys of Varians (ANOVA) atau F- test (uji-F)}

Menurut Santoso, (2018) ANOVA sering disebut juga dengan Uji F, mempunyai tujuan yang sama dengan uji t yakni menguji apakah rata-rata lebih dari dua sampel berbeda secara signifikan ataukah tidak dan menguji apakah dua sampel mempunyai varians populasi yang sama ataukah tidak.

Uji F digunakan untuk menguji model secara simultan atau keseluruhan. Apabila $\mathrm{F}_{\text {hitung }}>$ dari $\mathrm{F}_{\text {tabel }}$, maka model yang digunakan dapat dipakai sebagai parameyeter persamaan. Sebaliknya jika $F_{\text {hitung }}<\mathrm{F}$ tabel maka model yang digunakan tidak dapat dipakai sebagai penduga parameter.

\section{Koefesien Determinasi $\left(\mathbf{R}^{2}\right)$}

Koefesien determinasi bertujuan untuk mengukur seberapa jauh kemampuan model dalam menerangkan variabel-variabel independen memberikan hampir semua 
Neng Setiawati, Satya Wahyudi dan Novi Aulia, Analisis Efisiensi Dan Efektifitas Pajak Bumi dan Bangunan Perdesaan Dan Perkotaan (PBB-P2) dan Pengaruhnya terhadap Pendapatan Asli Daerah di Kabupaten Batang Hari

informasi yang dibutuhkan untuk memprediksi variabel dependen.

\section{HASIL DAN PEMBAHASAN}

Perkembangan Realisasi Penerimaan Pajak Bumi dan Bangunan Perdesaan dan Perkotaan (PBBP2)

Pajak Bumi dan Bangunan Perdesaan dan Perkotaan (PBB-P2) di Kabupaten Batang Hari dilaksanakan berdasarkan Peraturan Daerah Nomor 1 Tahun 2012 tentang Pajak Bumi dan Bangunan Perdesaan dan Perkotaan sebagai tindak lanjut implementasi Undang-Undang Nomor 28 Tahun 2009 tentang Pajak dan Retribusi Daerah, dimana PBB-P2 merupakan salah satu jenis pajak daerah yang menjadi penyumbang bagi Pendapatan Asli Daerah di Kabupaten Batang Hari.

PBB-P2 mrupakan salah satu dari 11 (sebelass) jenis pajak daerah yang dilaksanakan di Kabupaten Batang Hari. Penerimaan PBB-P2 secara keseluruhan memberikan kontribusi yang berarti bagi keuangan di Kabupaten Batang Hari. Perkembangan penerimaan PBB-P2 selama tahun 2016 sampai tahun 2020 dapat dilihat pada Tabel 4.1 berikut ini.

Tabel 4. Perkembangan Realisasi Penerimaan PBB-P2 Tahun 2016 - Tahun 2020 di Kabupaten Batang Hari

\begin{tabular}{cccc}
\hline No & Tahun & $\begin{array}{c}\text { Realisasi Penerimaan } \\
\text { PBB-P2 }\end{array}$ & $\begin{array}{c}\text { Tingkat } \\
\text { Pertumbuhan }(\%)\end{array}$ \\
\hline 1 & 2016 & $1.882 .517 .897,00$ & - \\
2 & 2017 & $2.461 .495 .665,00$ & 23,52 \\
3 & 2018 & $2.340 .009 .766,00$ & $-5,19$ \\
4 & 2019 & $2.628,796.179,00$ & 10,98 \\
5 & 2020 & $2.929 .338 .350,00$ & 10,26 \\
& Rata-rata & & 9,89 \\
\hline
\end{tabular}

Sumber: Badan Keuangan Daerah Kabupaten Batang Hari, 2021 (data diolah)

Dari tabel diatas dapat dijelaskan bahwa tingkat pertumbuhan penerimaan PBB-P2 setiap tahunnya dari tahun 2016 sampai dengan tahun 2020 berfluktuasi mengalami kenaikan dan penurunan, Kenaikan tertinggi adalah pada Tahun 2017 Rp2.461.495.665,00 naik sebesar Rp578.977.768,00 atau 23,52 persen dari tahun 2016 sebesar Rp. 1.882.517.897,00. Tingkat pertumbuhan terendah terjadi pada Tahun 2018 Rp2.340.009.766,00 turun sebesar Rp121.485.899,00 atau minus 5,19 dari tahun 2017. Rata-rata tingkat realisasi penerimaan PBB-P2 selama tahun 2016-2020 adalah sebesar 9,89 persen

Perkembangan Realisasi Penerimaan Pendapatan Asli Daerah
Tabel 5. Perkembangan Realisasi Penerimaan Pendapatan Asli Daerah Tahun 2016 - Tahun 2020 di Kabupaten Batang Hari

\begin{tabular}{cccc}
\hline No & Tahun & $\begin{array}{c}\text { Realisasi } \\
\text { Penerimaan PAD }\end{array}$ & $\begin{array}{c}\text { Tingkat } \\
\text { Pertumbuhan }(\%)\end{array}$ \\
\hline 1 & 2016 & $17.068 .815 .432,00$ & - \\
2 & 2017 & $25.265 .126 .787,09$ & 32,44 \\
3 & 2018 & $36.617 .780 .708,00$ & 31 \\
4 & 2019 & $21.672 .478 .405,58$ & $-68,96$ \\
5 & 2020 & $28.732 .670 .655,62$ & 24,57 \\
\hline & Rata-rata & & 4,76 \\
\hline
\end{tabular}

Sumber: Badan Keuangan Daerah Kabupaten Batang Hari, 2021 (data diolah)

Dari tabel diatas dapat dijelaskan bahwa tingkat pertumbuhan realisasi penerimaan PAD setiap tahunnya dari tahun 2016 sampai dengan tahun 2020 berfluktuasi mengalami kenaikan dan penurunan, Tingkat pertumbuhan kenaikan tertinggi PAD adalah pada Tahun 2017 Rp25.265.126.787,09 naik sebesar Rp8.196.311.355,09 atau 32,44 persen dari tahun 2016 sebesar Rp17.068.815.432,00. Tingkat pertumbuhan PAD terendah terjadi pada Tahun 2019 sebesar Rp21.672.478.405,58 atau turun sebesar Rp14.945.302,302,42 atau minus 68,96 persen dibandingkan tahun 2018 sebesar Rp36.617.780.708,00. Rata-rata tingkat realisasi penerimaan PAD selama tahun 2016-2020 adalah sebesar 4,76 persen. Terjadinya penurunan penerimaan PAD ini disebabkan karena terjadinya penurunan penerimaan pada beberapa Pos Pajak Daerah Berdasarkan Laporan Keuangan Daerah Kabupaten Batang Hari (2018) meningkatnya penerimaan Pajak daerah pada Tahun 2018 sebesar Rp18.294.829.079,00 salah satunya disumbangkan oleh Bea Perolehan Hak atas Tanah dan Bangunan (BPHTB) dikarenakan banyaknya perusahaan yang membayar BPHTB sebagai syarat pengajuan sertifikat Hak Guna Usaha (HGU) ke BPN. Sedangkan pada Tahun 2019 hanya beberapa perusahaan yang melakukan proses sertifikat HGU dan lahannya tidak seluas pada tahun 2018, akibatnya jumlah pembayaran BPHTB menjadi lebih kecil hanya sebesar Rp2.560.885.872,00

\section{Analisis Efisiensi Pajak Bumi dan Bangunan Perdesaan dan Perkotaan}

Analisis efisiensi penerimaan PBB-P2 dilakukan dengan membandingkan antara Biaya Pemungutan PBBP2 dengan Realisasi Penerimaan PBB-P2. Biaya pemungutan PBB-P2 ini terdiri dari Biaya ATK, Biaya Perjalanan Dinas dan Biaya cetak Surat Pemberitahuan Pajak Terutang (SPPT). Analisis dalam pembahasan ini menggunakan realisasi penerimaan PBB-P2 dan Biaya Pemungutan PBB-P2 selama 5 (lima) Tahun Anggaran yaitu dari Tahun Anggaran 2016-2020. Semakin besar angka perhitungan yang diperoleh menunjukkan kurang efisiennya PBB-P2, sedangkan apabila semakin kecil angka efisiensi yang diperoleh dari hasil perhitungan 
Neng Setiawati, Satya Wahyudi dan Novi Aulia, Analisis Efisiensi Dan Efektifitas Pajak Bumi dan Bangunan Perdesaan Dan Perkotaan (PBB-P2) dan Pengaruhnya terhadap Pendapatan Asli Daerah di Kabupaten Batang Hari

menunjukan penerimaan PBB-P2 sangat efisien, artinya hasil yag didapat lebih besar dari Biaya Pemungutan dari PBB-P2 tersebut..
Perhitungan efisiensi penerimaan Pajak Bumi dan Bangunan Perdesaan dan Perkotaan di Kabupaten Batang Hari selama 5 (lima) Tahun Anggaran 2016 2020 seperti Tabel berikut.

Tabel 6. Perkembangan Realisasi Penerimaan PBB-P2 serta Biaya Pemungutan PBB - P2 Tahun 2016 - Tahun 2020 di Kabupaten Batang Hari

\begin{tabular}{ccccc}
\hline No & Tahun & Realisasi Penerimaan PBB-P2 & Biaya Pemungutan PBB - P2 & Efisiensi (\%) \\
\hline 1 & 2016 & $1.882 .517 .897,00$ & $2.874 .540 .336,00$ & 152,70 \\
2 & 2017 & $2.461 .495 .665,00$ & $2.990 .548 .532,00$ & 121,49 \\
3 & 2018 & $2.340 .009 .766,00$ & $1.046 .568 .664,00$ & 44,72 \\
4 & 2019 & $2.628,796.179,00$ & $2.282 .612 .413,00$ & 86,83 \\
5 & 2020 & $2.929 .338 .350,00$ & $281.509 .193,00$ & 9,16 \\
\hline
\end{tabular}

Sumber: Badan Keuangan Daerah Kabupaten Batang Hari Tahun, 2021 (data diolah)

Berdasarkan Tabel diatas terlihat bahwa berdasarkan hasil perhitungan data tingkat efisiensi PBB-P2 yang tidak efisien terjadi apabila nilai efisiensinya berada diatas 100 persen artinya tingkat efisiensi yang paling rendah terjadi pada Tahun 2016 sebesar 152,70 persen termasuk dalam kategori kurang efisien, hal ini disebabkan karena biaya pemungutan PBB-P2 lebih besar daripada realisasi penerimaan PBB$\mathrm{P} 2$.

Sedangkan tingkat efisiensi yang sangat efisien terjadi pada Tahun 2020 sebesar 9,16 persen. Tingginya tingkat efisiensi pada Tahun 2020 dikarenakan terjadinya pengurangan anggaran untuk biaya pemungutan seperti ATK maupun perjalanan dinas pegawai atau petugas ke lapangan akibat refocusing APBD dalam menghadapi Corona Virus Diases-19 (Covid-19) sehingga beberapa item biaya pemungutan dihilangkan. Tingkat efisiensi pemungutan PBB-P2 selama Tahun 2016 sampai Tahun 2020 di Kabupaten Batang Hari berkisar antara 9,16 persen hingga 152,70 persen. Hal ini berarti untuk mendapatkan penerimaan PBB-P2 sebesar Rp100.000.000,00 diperlukan biaya pemungutan sebesar Rp9.160.000,00 sampai dengan $152.700 .000,00$
Rata-rata tingkat efisiensi pemugutan PBB-P2 selama Tahun 2016 sampai Tahun 2020 menunjukkan angka efisiensi sebesar 82,98 persen, dapat dikatakan bahwa tingkat efisiensi pemungutan PBB-P2 di Kabupaten Batang Hari termasuk dalam kategori cukup efisien.

\section{Analisis Efektivitas Pajak Bumi dan Bangunan Perdesaan dan Perkotaan}

Analisis efektivitas penerimaan PBB-P2 dilakukan dengan membandingkan antara realisasi penerimaan PBB-P2 dengan target PBB-P2 selama 5 (lima) Tahun Anggaran yaitu dari Tahun Anggaran 2016-2020. Semakin besar angka perhitungan yang diperoleh menunjukkan penerimaan PBB-P2 efektif, karena sesuai dengan kriteria nilai efektifitas dari Depdagri apabila angka persentase berada pada range 90 -100 persen termasuk kedalam kriteria efektif. sedangkan apabila semakin kecil angka efektifitas yang diperoleh maka termasik kriteria nilai yang tidak efektif ( $<60$ persen).

Perhitungan efektivitas penerimaan Pajak Bumi dan Bangunan Perdesaan dan Perkotaan di Kabupaten Batang Hari selama 5 (lima) Tahun Anggaran 2016 2020 seperti Tabel berikut.

Tabel 7. Perkembangan Realisasi Penerimaan PBB-P2 serta Target Penerimaan PBB - P2 Tahun 2016 - Tahun 2020 di Kabupaten Batang Hari

\begin{tabular}{ccccc}
\hline No & Tahun & Realisasi Penerimaan PBB-P2 & Target Penerimaan PBB - P2 & Efektivitas (persen) \\
\hline 1 & 2016 & $1.882 .517 .897,00$ & $2.315 .000 .000,00$ & 81,32 \\
2 & 2017 & $2.461 .495 .665,00$ & $2.500 .000 .000,00$ & 98,46 \\
3 & 2018 & $2.340 .009 .766,00$ & $4.500 .000 .000,00$ & 52,00 \\
4 & 2019 & $2.628,796.179,00$ & $5.000 .000 .000,00$ & 52,57 \\
5 & 2020 & $2.929 .338 .350,00$ & $5.600 .000 .000,00$ & 52.31 \\
\hline
\end{tabular}

Sumber: Badan Keuangan Daerah Kabupaten Batang Hari Tahun, 2021 (data diolah)

Tabel diatas menggambarkan efektivitas penerimaan Pajak Bumi dan Bangunan Perdesaan dan Perkotaan menunjukan bahwa nilai efektivitas penerimaan Pajak Bumi dan Bangunan Perkotaan dan Perdesaan di Kabupaten Batang Hari berfluktuasi dari tahun ke tahun dengan angka berkisar 52,00 persen sampai dengan 98,46 persen dengan tingkat efektivitas rata-rata sebesar 56,87 persen termasuk kategori kurang efektif.

Berdasarkan Tabel 7 terlihat bahwa tingkat efektivitas PBB-P2 yang tertinggi terjadi pada Tahun 2017 sebesar 98,46 persen. Tingkat efektivitas yang 
terendah terjadi pada 3 Tahun Anggaran yaitu Tahun Anggaran 2018, 2019 dan 2020 yaitu masing-masing 52,00 persen, 52,57 persen, dan 52,31 persen yang termasuk dalam kriteria tidak efektif, hal ini disebabkan karena realisasi penerimaan PBB-P2 lebih kecil daripada target penerimaan PBB-P2 yang telah ditetapkan.

Tingginya nilai tingkat efektivitas penerimaan PBB-P2 pada Tahun 2017 belum menunjukkan besarnya tingkat efektivitas yang sebenarnya, karena penilaian efektivitas hanya berdasarkan target tidak berdasarkan potensi PBB-P2 yang ada, apalagi target tersebut biasanya dibandingkan dengan target tahun sebelumnya sehingga menyebabkan potensi PBB -P2 yang sebenarnya tidak diketahui.

\section{Analisis Kontribusi PBB-P2 terhadap Pendapatan Asli Daerah (PAD)}

Tabel 8. Perkembangan Realisasi Penerimaan PAD serta Realisasi Penerimaan PBB - P2 Tahun 2016 - Tahun 2020 di Kabupaten Batang Hari

\begin{tabular}{ccccc}
\hline No & Tahun & Realisasi Penerimaan PAD & Realisasi Penerimaan PBB - P2 & Kontribusi/Share (\%) \\
\hline 1 & 2016 & $17.068 .815 .432,00$ & $1.882 .517 .897,00$ & 11,03 \\
2 & 2017 & $25.265 .126 .787,09$ & $2.461 .495 .665,00$ & 9,74 \\
3 & 2018 & $36.617 .780 .708,00$ & $2.340 .009 .766,00$ & 6,39 \\
4 & 2019 & $21.672 .478 .405,58$ & $2.628,796.179,00$ & 12,12 \\
5 & 2020 & $28.732 .670 .655,62$ & $2.929 .338 .350,00$ & 10,20 \\
\hline
\end{tabular}

Sumber: Badan Keuangan Daerah Kabupaten Batang Hari Tahun, 2021 (data diolah)

Dari Tabel diatas dapat dilihat bahwa kontribusi PBB-P2 terhadap PAD selama Tahun Anggaran 2016 sampai Tahun Anggaran 2020 menunjukkan fluktuasi, dimana kontribusi yang terbesar terjadi pada Tahun Anggaran 2019 sebesar 12,12 persen. Hal ini disebabkan adanya kesadaran dari Wajib Pajak untuk membayar PBB-P2 sesuai besarnya nilai nominal tagihan pada Surat Pemberitahuan Pajak Terutang (SPPT). Sedangkan kontribusi terkecil terjadi pada Tahun Anggaran 2018 sebesar 6,39 persen hal ini disebabkan karena belum optimalnya pelaksanaan sosialisasi PBB-P2 kepada masyarakat. Sedangkan rata-rata kontribusi PBB-P2 terhadap PAD sebesar 10,20 persen, hal ini tergolong kurang, karenanya diperlukan upaya yang lebih baik lagi didalam peningkatan penerimaan PBB-P2 sehingga akhirnya akan memberikan kontribusi yang signifikan bagi Pendapatan Asli Daerah (PAD) sebagai salah satu sumber dari Anggaran Pendapatan dan Belanja Daerah (APBD) di Kabupaten Batang Hari.

\section{Analisis Pengaruh PBB-P2 terhadap Pendapatan Asli Daerah (PAD)}

Untuk melihat pengaruh PBB-P2 terhadap PAD di Kabupaten Batang Hari digunakan analisis regresi regresi linear sederhana. Persamaan regresi pengaruh PBB-P2 terhadap Pendapatan Ali Daerah selama Tahun Anggaran 2016 - Tahun Anggaran 2020 dapat dilihat sebagai berikut:

Tabel 9. Hasil Uji Koefisien

\begin{tabular}{|c|c|c|c|c|c|c|}
\hline \multirow{2}{*}{\multicolumn{2}{|c|}{ Model }} & \multicolumn{2}{|c|}{ Unstandardized Coefficients } & \multirow{2}{*}{$\begin{array}{c}\text { Standardized Coefficients } \\
\text { Beta } \\
\end{array}$} & \multirow[b]{2}{*}{$\mathrm{t}$} & \multirow[b]{2}{*}{ Sig. } \\
\hline & & $\mathrm{B}$ & Std. Error & & & \\
\hline \multirow[t]{2}{*}{1} & (Constant) & 7683944072,723 & 25238053175,002 & & ,304 & ,781 \\
\hline & PBBP2 & 7,428 & 10,207 & ,387 & ,728 &, 519 \\
\hline
\end{tabular}

a. Dependent Variable: PAD

Sumber: IBM SPSS 26

$\mathrm{Y}=7.683 .944 .073+7.428 \mathrm{x}$

$\mathrm{PAD}=\mathrm{a}+\mathrm{bx}$

$\mathrm{Y}=$ Pendapatan Asli Daerah (PAD)

$\mathrm{x}=$ Pajak Bumi dan Bangunan Perdesaan dan Perkotaan (PBB-P2)

Nilai koefisien regresi yang diperoleh dari pengolahan data SPSS 26 adalah sebesar 7,428 artinya apabila Pajak Bumi dan Bangunan Perdesaan dan Perkotaan mengalami perubahan sebesar Rp100.000.000, 00 maka Pendapatan Asli Daerah akan meningkat sebesar Rp7.428.000,00
Untuk melihat tingkat hubungan antara PBB-P2 dan PAD di Kabupaten Batang Hari dapat dilihat dari koefisien korelasi anatara dua variabel yang diteliti. Dari hasil perhitungan diperoleh nilai koefisien korelasi (r) sebesar 0,387 artinya 38,7 persen perubahan penerimaan PAD Kabupaten Batang Hari ditentukan oleh perubahan PBB-P2, sedangkan 61,3 persen ditentukan oleh faktor lain yang tidak diteliti. Nilai koefisen korelasi PBB-P2 ini menunjukkan bahwa perubahan penerimaan PBB-P2 sebesar Rp1.000.000,00 akan mengakibatkan PAD meningkat sebesar Rp387.000,00

Hasil perhitungan secara parsial (Analisis $\mathbf{t}$ - Test) 
Uji t dipergunakan untuk melihat keberartian nilai koefisien regresi antara variabel dependent (PAD) dengan variabel independent (PBB-P2) secara individual. Uji t dilakukan dengan tingkat signifikansi 0,05 persen dengan uji 2 (dua) arah /two tail, (to,05) dengan derajat kebebasan (n-k), diperoleh nilai t hitung sebesar 0,728 dan nilait $t$ tabel sebesar 3,182. Hal ini berarti bahwa t hitung $<\mathrm{t}$ tabel sehingga Ho di tolak, keadaan ini berarti bahwa variabel x (PBB-P2) tidak berpengaruh terhadap variabel $\mathrm{Y}$ Pendapatan Asli Daerah (PAD) di Kabupaten Batang Hari.

\section{Hasil perhitungan secara simultan Koefisien Determinasi}

Koefisien determinasi $\left(\mathrm{R}^{2}\right)$ atau koefisien penjelas dipergunakan untuk mengukur besarnya tingkat hubungan secara simultan (keseluruhan) antara variabel dependent dan variabel independent

Tabel 10. Hasil Uji Koefisien Determinasi

Model Summary

\begin{tabular}{lr|rrrr} 
Model & R & \multicolumn{2}{|c|}{ R Square } & Adjusted R Square & Std. Error of the Estimate \\
\hline 1 &, $387^{\mathrm{a}}$ &, 150 &,- 133 & 7879723860,83540 \\
\hline
\end{tabular}

a. Predictors: (Constant), PBBP2

Sumber: IBM SPSS 26

Tabel 11. Hasil Uji Analisis of Varian (ANOVA)

\begin{tabular}{|c|c|c|c|c|c|c|}
\hline Model & & Sum of Squares & $\underset{\mathrm{df}}{\mathbf{A N O V A}}$ & Mean Square & $\mathrm{F}$ & Sig. \\
\hline \multirow[t]{3}{*}{1} & Regression & 32885428555223822000,000 & 1 & 32885428555223822000,000 & .530 & $.519^{\mathrm{b}}$ \\
\hline & Residual & 186270144369056060000,000 & 3 & 62090048123018680000,000 & & \\
\hline & Total & 219155572924279880000,000 & 4 & & & \\
\hline
\end{tabular}

a. Dependent Variable: PAD

b. Predictors: (Constant), PBBP2

Sumber: IBM SPSS 26

Dari hasil perhitungan diperoleh nilai $\mathrm{R}^{2}$ sebesar 0,150. Nilai koefisien determinasi ini menunjukkan bahwa 15 persen hubungan PAD dapat dijelaskan oleh Penerimaan Pajak Bumi dan Bangunan Perdesaan dan Perkotaan (PBB-P2), sedangkan sisanya sebesar 85 persen disebabkan oleh faktor lain yang tidak diteliti. Dengan demikian dapat dikatakan bahwa PBB-P2 tidak mempunyai hubungan yang nyata terhadap penerimaan Pendapatan Asli Daerah

Sementara itu dalam menguji model secara simultan atau keseluruhan dilakukan uji F. Uji $F$ dilakukan dengan menggunakan tingkat keyakinan 95 persen diperoleh perhitungan $\mathrm{F}$ hitung sebesar 0,530 sedangkan $\mathrm{F}$ tabel sebesar 10,13. Berarti $\mathrm{F}$ hit $<\mathrm{F}$ tabel, keadaan ini berarti bahwa PBB-P2 secara keseluruhan tidak berpengaruh terhadap penerimaan PAD di Kabupaten Batang Hari.

\section{SIMPULAN}

1 Rata-rata tingkat realisasi penerimaan PBB-P2 selama tahun 2016-2020 adalah sebesar 9,89 persen, dengan tingkat pertumbuhan berkisar antara $-5,19$ persen sampai 23,52 persen. Tingkat pertumbuhan PBB-P2 tertinggi terjadi pada Tahun Anggaran 2017 yaitu sebesar 23,52 persen serta tingkat pertumbuhan terendah terjadi pada Tahun Anggaran 2018 sebesar 5,19 persen.

2 Rata-rata kontribusi PBB-P2 terhadap PAD sebesar 10,20 persen, hal ini tergolong kurang, Kontribusi
PBB-P2 terhadap PAD selama Tahun Anggaran 2016 sampai Tahun Anggaran 2020 menunjukkan fluktuasi, dimana kontribusi yang terbesar terjadi pada Tahun Anggaran 2019 sebesar 12,12 persen, hal ini disebabkan adanya kesadaran dari Wajib Pajak untuk membayar PBB-P2 sesuai besarnya nilai nominal tagihan pada Surat Pemberitahuan Pajak Terutang (SPPT). Sedangkan kontribusi terkecil terjadi pada Tahun Anggaran 2018 sebesar 6,39 persen hal ini disebabkan karena belum optimalnya pelaksanaan sosialisasi PBB-P2 kepada masyarakat.

3 Rata-rata tingkat efisiensi pemugutan PBB-P2 selama Tahun 2016 sampai Tahun 2020 menunjukkan angka efisiensi sebesar 82,98 persen, dapat dikatakan bahwa tingkat efisiensi pemungutan PBB-P2 di Kabupaten Batang Hari termasuk dalam kategori cukup efisien artinya untuk mendapatkan penerimaan Pajak Bumi dan Bangunan Perdesaan dan Perkotaan (PBB-P2) sebesar Rp100.000.000,00 dibutuhkan biaya pungut sebesar Rp82.980.000,00. Tingkat efisiensi pemungutan PBB-P2 yang paling rendah terjadi pada Tahun Anggaran 2016 yaitu sebesar 152,70 persen termasuk dalam kategori kurang efisien, hal ini disebabkan Karena biaya pemungutan PBB-P2 lebih besar daripada realisasi penerimaan PBB-P2. Sedangkan tingkat efisiensi yang sangat efisien terjadi pada Tahun 2020 sebesar 9,16 persen. Tingginya tingkat efisiensi pada Tahun 2020 dikarenakan terjadinya pengurangan anggaran untuk 
biaya pemungutan seperti ATK maupun perjalanan dinas ke lapangan akibat refocusing APBD dalam menghadapi Corona Virus Diases-19 (Covid-19) sehingga beberapa item biaya pemungutan dihilangkan.

4 Rata-rata tingkat efektifitas PBB-P2 sebesar 56,87 persen artinya dari target PBB-P2 yang telah ditetapkan mampu merealisasikan penerimaan PBB$\mathrm{P} 2$ rata-rata sebesar 56,87 persen. tingkat efektivitas PBB-P2 yang tertinggi terjadi pada Tahun 2017 sebesar 98,46 persen. Tingkat efektivitas yang terendah terjadi pada 3 Tahun Anggaran yaitu Tahun Anggaran 2018, 2019 dan 2020 yaitu masing-masing 52,00 persen, 52,57 persen, dan 52,31 persen yang termasuk dalam kriteria tidak efektif, hal ini disebabkan karena realisasi penerimaan PBB-P2 lebih kecil daripada target penerimaan PBB-P2 yang telah ditetapkan.

5 Nilai koefisien korelasi (R) sebesar 0,387 artinya 38,7 persen perubahan penerimaan PAD Kabupaten Batang Hari ditentukan oleh perubahan PBB-P2, sedangkan 61,3 persen ditentukan oleh faktor lain yang tidak diteliti. Nilai koefisen korelasi PBB-P2 ini menunjukkan bahwa perubahan penerimaan PBB-P2 sebesar Rp1.000.000,00 akan mengakibatkan PAD meningkat sebesar Rp387.000,00

6 Berdasarkan pengujian terhadap nilai t, diperoleh nilai $t$ hitung sebesar 0,728 dan nilai $t$ tabel sebesar 3,182 . Hal ini berarti bahwa $\mathrm{t}$ hitung $<\mathrm{t}$ tabel sehingga Ho di tolak, keadaan ini berarti bahwa variabel $\mathrm{x}$ (PBB-P2) tidak berpengaruh terhadap variabel Y Pendapatan Asli Daerah (PAD) di Kabupaten Batang Hari.

7 Nilai koefisien determinasi $\left(\mathrm{R}^{2}\right)$ sebesar 0,150 . Nilai koefisien determinasi ini menunjukkan bahwa 15 persen hubungan PAD dapat dijelaskan oleh Penerimaan Pajak Bumi dan Bangunan Perdesaan dan Perkotaan (PBB-P2), sedangkan sisanya sebesar 85 persen disebabkan oleh faktor lain yang tidak diteliti. Dengan demikian dapat dikatakan bahwa PBB-P2 tidak mempunyai hubungan yang nyata terhadap penerimaan Pendapatan Asli Daerah.

8 Berdasarkan perhitungan diperoleh nilai $\mathrm{F}$ hitung sebesar 0,530 sedangkan nilai $F$ tabel sebesar 10,13. Uji $F$ dilakukan dengan menggunakan tingkat keyakinan 95 persen. Berarti $\mathrm{F}$ hit $<\mathrm{F}$ tabel, keadaan ini berarti bahwa Ho ditolak atau Ha diterima. Berarti secara keseluruhan PBB-P2 tidak berpengaruh terhadap penerimaan PAD di Kabupaten Batang Hari.

\section{Saran}

Berdasarkan hasil kesimpulan, maka penulis memberikan saran dalam meningkatkan peran PBB-P2 dalam meningkatkan penerimaan PAD di Kabupaten Batang Hari agar dapat memberikan kontribusi yang lebih baik lagi dimasa mendatang pada tingkat fiskal daerah yaitu sebagai berikut:

1. Meningkatkan tingkat efisiensi pemungutan PBB-P2 dengan cara meminimumkan biaya-biaya pemungutan yang tidak diperlukan atau biaya yang tidak mendesak agar hasil yang didapatkan lebih besar dari biaya-biaya yang dikeluarkan untuk memungut PBB-P2.

2. Meningkatkan tingkat efektifitas penerimaan PBB-P2 dengan menggali potensi PBB-P2 yang ada di Kabupaten Batang Hari dengan cara ekstensifikasi pajak seperti mendata kembali Wajib Pajak PBB-P2 yang tersebar di setiap Kecamatan, Kelurahan, Desa maupun tingkat Rukun Tetangga (RT), karena penilaian efektivitas selama ini hanya berdasarkan target tidak berdasarkan potensi PBB-P2 yang sebenarnya ada di lapangan, apalagi target tersebut biasanya hanya dibandingkan dengan target tahun sebelumnya sehingga menyebabkan potensi riil $\mathrm{PBB}-$ $\mathrm{P} 2$ yang sebenarnya tidak diketahui.

3. Mengingat PBB-P2 tidak berpengaruh nyata terhadap penerimaan $\mathrm{PAD}$, maka perlu melaksanakan perbaikan manajemen penerimaan PBB-P2 dengan cara intensifikasi pajak di era digital seperti mengoptimalkan serta memperluas akses sistem Informasi Teknologi (IT) melalui sistem pembayaran secara online di bank-bank daerah maupun Bank Nasional yang terkoneksi dengan jaringan Automatic Teller Machine (ATM) link mobile online seluruh Indonesia.

4. Menerapkan reward dan punishment bagi pegawai pengelola PBB-P2, dengan cara meningkatkan Sumber Daya Manusia (SDM) di Bidang PBB-P2 melalui Bimbingan Teknis dan Pelatihan, maupun insentif keuangan berdasarkan besarnya realisasi Pajak Bumi dan Bangunan Perdesaan dan Perkotaan yang dapat dikumpulkan, serta menerapkan sanksi apabila terjadi penyimpangan penerimaan pajak di lapangan.

5. Melaksanakan evaluasi minimal setiap bulan antara pimpinan dengan pegawai di Bidang PBB-P2. Pimpinan hendaknya juga melakukan pengecekan langsung ke lapangan agar masalah-masalah yang tersembunyi dapat diketahui dan dicari solusi dari masalah tersebut.

6. Memperbaharui secara akurat tarif Nilai Jual Objek Pajak (NJOP) berdasarkan Klasifikasi Zonasi PBBP2 pada Surat Keputusan Bupati Batang Hari setiap 3 (tiga) tahun sekali dengan melihat tingkat perkembangan perekonomian daerah, sehingga diharapkan penerimaan PBB-P2 akan memberikan kontribusi yang lebih besar dan berpengaruh nyata terhadap penerimaan PAD di Kabupaten Batang Hari. 


\section{DAFTAR PUSTAKA}

Badrudin, Rudy dan Mufidhatul Khasanah, 2011, Pengaruh Pendapatan dan Belanja Daerah Terhadap Pembangunan Manusia di Provinsi Daerah Istimewa Yogyakarta, Jurnal Manajemen, Akuntansi, dan Ekonomi Pembangunan, Vol.9 No.1.

Gitaningtyas, Yetty Kurniawati, 2014, Pengaruh PDRB, jumlah Penduduk, dan Investasi Swasta terhadap realisasi PAD pada Kabupaten/Kota di Provinsi Jawa Timur, Skripsi, Universitas Jember.

Hafidh, Aula Ahmad, 2013, Analisis Rasio Keuangan Daerah Dalam Mempengaruhi Belanja Modal Publik Bagi Pertumbuhan Ekonomi

Halim, Abdul, 2011, Manajemen Keuangan Sektor Publik, Salemba Empat, Jakarta

Litbang Depdagri dan FISIPOL - UGM,1991, Pengukuran Kemampuan Keuangan Daerah Tingkat II Dalam Rangka Otonomi Daerah Yang Nyata dan Bertanggung Jawab, Jakarta.

Mahmudi, 2010, Analisis Laporan Keuangan Pemerintah Daerah, UPP STIM YKPN, Yogyakarta

Mardiasmo, 2002, Akuntansi Sektor publik, Andi, Yogyakarta.

Mukhlis, Imam, 2010, Peran Pajak Daerah dalam Meningkatkan Pendapatan Asli Daerah, Makalah Disampaikan pada acara seminar regional perpajakan yang diselenggarakan oleh Fakultas Ekonomi Univesitas Negeri Malang

Peraturan Daerah Kabupaten Batang Hari Nomor 1 Tahun 2012 tentang Pajak Bumi dan Bangunan.

Republik Indonesia, UU No. 28 Tahun 2009 tentang Pajak Daerah dan Retribusi Daerah.

Santoso, Singgih, 2020, Panduan Lengkap SPSS 26, PT. Elex Media Komputindo, Jakarta.

Santoso, Singgih, 2020, Mahir Statistik Parametrik, PT. Elex Media Komputindo, Jakarta.

Sugiyono, 2001, Metode Penelitian Bisnis, CV. Alfabeta, Bandung.

Ramadhayanti, Ana, 2019, Aplikasi SPSS Untuk Penelitian dan Riset Pasar, PT. Elex Komputindo, Jakarta.

Kepmendagri No. 690.900.327, 1996

Tentang Pedoman Penilaian dan Kinerja Keuangan

Tuasikal, Askam, 2008, Pengaruh DAU, DAK, PAD dan PDRB terhadap Belanja Modal Pemerintah Daerah kab/kotadi Indonesia, Jurnal Telaah dan Riset Akuntansi Vol. 1 No. 2, Universitas Pattimura, Ambon.

Utomo, Okta Sigit, 2012, Analisis Pengaruh Pajak daerah dan Retribusi daerah Terhadap Pendapatan Asli Daerah (Studi Kasus di DPPKAD Wilayah Keresidenan Surakarta), Universitas Muhammadiyah Surakarta. 